\title{
Patronage Buying Motives of Milkindo's Tourists
}

\author{
Mega Mirasaputri Cahyanti", Widiya Dewi Anjaningrum \\ Department of Management, Faculty of Economics and Business, Institute Technology and Business Asia Malang, \\ Indonesia
}

Abstract

Agritourism with the concept of animal husbandry has its own uniqueness as a tourist destination. Among Agritourism at Malang City, Indonesia, with the concept of animal husbandry, only Milkindo stated their place as integrated dairy farming for recreation and education. The purpose of this study was to determine the relationship of patronage buying motives consisting of tourist sites, tourist location atmosphere, facilities at tourist sites, price \& service quality to the decision process of tourists visiting tourism of the Milkindo Integrated Dairy Farming Recreational and Educational Tours. One hundred Samples were selected on a non-probability sampling with an accidental sampling approach. Quantitative Data is analysed by Partial Least Square (PLS) analysis. The result of this study is shown that facilities at tourist sites is the one variable that has a significant positively effect on the decision process of tourists visiting tourist sites, while the tourist location, tourist location atmosphere, and service quality don't have significant effect on it, meanwhile price has a negative but not significant effect. The findings show that the theory of motive theory of tourist's patronage buying motive toward Milkindo can be used as a basis for assessing attractions other than agritourism. In addition, it can be translated with different geographical and demographic conditions, because the study is only in the city of Malang, Indonesia.

Keywords: Agritourism with Farming Concept, Patronage Buying Motives, Tourist Visiting Behaviour.

\section{INTRODUCTION}

Agritourism with the animal farming concept has its own uniqueness as a tourism destination. There are 3 (three) locations in Malang City and surrounding areas built as recreational destinations, which are Mega Star (horse farming) at Batu, Nusa Pelangi and Milkindo (dairy farming). Among those agritourism with the animal farming concept, only Milkindo stated their place as an integrated dairy farming for recreational and educational tours. The integrated farming concept is a sustainable system that does not stand alone and believes that everything produced will return to nature as their principle. It means every waste produced will be reused into something valuable [1].

In integrated farming concept that developed in many countries has a zero-waste production system as its orientation. It means every waste produced from cattle and plants will be recycled and reuse into the cycle production cycle [2]. Those interesting concepts of Milkindo are created to attract tourists to visit and spend their leisure time to have a vacation activity with their family in this area.

The explanation above makes the reason why Milkindo becomes the subject of this study. Also, based on the observation that the researcher did, the latest problem on Milkindo was ineffective promotions carried out by their Management

\footnotetext{
* Correspondence address:

Mega Mirasaputri Cahyanti

Email : mega_mc@yahoo.co.id

Address : Jl. Borobudur No.21 Malang
}

which made the declined in the number of tourists. The issue happened by lacking detailed information owned by Milkindo's Management on what things actually attracted Milkindo's tourists. By obtaining clear information about what factors make the tourists interested, and emphasizing it as a promotion tool to attract new potential tourists, then we will find an effective way to do promotion.

Every vacation activity, to meet the needs of life, motivated by different reasons. Thus, it is important to understanding tourist's motivation, especially for social and cultural reasons. It is because those things will affect tourist's preference for the type of tour they want. Various types of tourism products and services offered by tourism destinations nowadays were led to various choices faced by potential tourists.

Since there is no official promotion from Milkindo, word-of-mouth information is the reason for tourists' decision to visit Milkindo. However, different tourists will have different experiences, so the satisfaction level of tourists will also differ. In general, every tourist will tell their satisfaction and dissatisfaction experience to other people. So it creates a fluctuation effect on the amount of the tourist visiting the tourism destination indirectly. Thus, to meet tourist's demands and needs that' always change and demanding, the management of Milkindo has to manage each element about Patronage buying motives professionally.

Research needs to be done to determine the indicators of Patronage buying motives that need 
to be prioritized by Milkindo's management to influence the tourist visiting behavior on Milkindo. The result of this research was expected to predict the change of tourist preferences so that Milkindo will be able to compete in the tourism industry. Previous research defined consumer behavior in tourism as the study of why people buy the products and how they make their decisions [3]. Each tourist has different behavior in deciding to choose a tourism destination. Other research explained buying decision conducted by a consumer is a conscious activity as a response to a problem [4].

Several studies with different instruments that explained purchase patterns and customer motivation were differentiated into two motives. The first is product motives, which cover all reasons or interest so that someone buys a product, and the second is motive to buy from the dealer who sells the product or a place of purchase (patronage motive). This motive is a consideration for consumers buying in a certain place. Pertiwi [5] argued that patronage buying motives are the reasons why a consumer chooses to shop at a store. In this study, the researcher replaces the stores with a tourism destination which is Milkindo, as integrated dairy farming.

The elements of Patronage buying motives explained by previous researches were simplified into five elements $[6,7]$. This consideration is based on the reason that some elements of the Patronage buying motives have almost the same meaning. So that, five elements of patronage buying motives in this research are: (1) tourist location, (2) ambiance at tourism destination, (3) facilities at tourism destination, (4) price at tourism destination, (5) service quality by human resources at tourism destination. As a rule, the closer area is to its likely markets, the more desirable it is and the more likely it to have a high demand [8].

Most tourists judge a tourist destination based on what is visible from a tourist attraction, such as architecture from the outside, which ultimately can make tourists decide whether to visit these attractions or not [9]. It also depends on the perception of each tourist whether the tourist destinations are right for them or not.

Another important thing that can influence purchasing behavior is the quality of the ambiance around the tourism destination or ecological design at the tourist location. Tourists will feel comfortable staying longer in a tourism destination if the ambiance at the tourist destination could give a happy and feel comfortable feeling during their tourism activities. In addition to the density of visitors, the seller of food and beverage around the tourism destination is also a component that determines whether the ambiance is comfortable in the tourism destination. Thus, the relationship between people has reciprocal effects that can be positive or negative.

If tourists doing the tourism activities, which starts from leaving from their home toward tourism destination, surely need a various thing, such as transportation facilities, food, drinks, recreational facilities, even lodging. Offers must be available in sufficient quantities following the requests of visitors who come to the destination [8]. Each facility offered by a tourism destination can influence tourist's visiting behavior $[6,7]$.

Other variables that also important to be considered in choosing a tourism destination are price, value, product variation, quality, cleanliness of tourist attractions, and the friendliness of employees who serve tourists while they are at tourist attractions [6]. Pricing is often used as a competitive advantage tool in tourism in several ways to try and influence consumers in their purchasing patterns [3]. Various prices between holidays and weekdays, or between peak-season and off-season, are some of the company's strategies toward price to tourists. Each visit to a tourism destination also depends on the time owned by tourists to visit. Usually, many people travel on weekends or school holidays, or national holidays.

Finally, employees are instruments that also greatly affect the store's image [6]. Tourists as consumers tend to wish that company employees can help if they need help (helpful), friendly, and polite (courteous). This condition will make a tourist spend more time at the tourism destination because they are served by employees nicely. If the tourist stays longer in tourism destination, they will tend to spend more on their money. Likewise, the quality of the human resources as a manager is required to be professional to manage the tourism destination nicely. It is because every good service tends to create and even maintain tourist satisfaction. Tourist satisfaction is one of the keys to the final relationship with consumers and giving value to them [9].

The current discussion about patronage buying motives is more related to spending centers, including hypermarkets and malls. Based on previous research, motives for patronage purchases to malls, retail stores, and other 
shopping centers are very diverse, including social motives, personal motives, searching for motivation, searching for motivational experiences, prices, interior design, intrinsic and extrinsic motives, excitement, utilitarian motives, looking for variations, hedonic motifs, and others $[10,11,12]$. Studies on motives of patronage buying in the shopping center were also done by God in 1997, Ruiz in 1999, Dennis et al. in 2001, and Nicholls et al. in 2000 and 2002 [13]. But still few previous researches about patronage motives buying to discover tourist decision making toward visiting tourism destination. So the aims of this study were to determine whether: 1) there is an effect of tourist location toward tourist visiting behavior process significantly, 2) there is an effect of atmosphere at tourism destination toward tourist visiting behavior process significantly, 3) there is an effect of available facilities at tourism destination toward tourist visiting behavior process significantly, 4) there is an effect of price at tourism destination toward tourist visiting behavior process significantly, 5) there is an effect of service quality by human resources at tourism destination toward tourist visiting behavior process significantly.

\section{MATERIAL AND METHOD}

The object of this research is the Milkindo Integrated Dairy Farming Recreational and Educational Tours. Samples were selected on a non-probability sampling with an accidental sampling approach. Accidental sampling, also known as grab or opportunity sampling, is a form of non-probability sampling that involves taking a population sample that is close at hand rather than carefully determined and obtained. In this research, the researcher finds a person who visits Milikindo by randomly selecting passers-by using a questionnaire. The population is unknown, so the number of samples in this study was based on the formula for calculating samples in unknown populations as follows [14].

$$
n=\left(\frac{Z_{\alpha / 2} \sigma}{e}\right)^{2}=\left(\frac{(1,96) \cdot(0,25)}{0,05}\right)^{2}=96,04
$$

Thus, the samples taken in this study were rounded up to 100 respondents. Data collection is done by field survey method, with 5 points scale questionnaire instruments. The collected data is processed and analysed using Partial Least Square (PLS) analysis using SmartPLS software version 3.2.8. The Independent variable summarized in Table 1 is Patronage buying motives $(X)$, based on Stanton and Shadish [7]. It was divided into 5 (five) parts, i.e. tourist sites $\left(X_{1}\right)$, tourist location atmosphere $\left(X_{2}\right)$, Facilities at tourist sites $\left(X_{3}\right)$, Price $\left(X_{4}\right)$, Quality of Service $\left(X_{5}\right)$. While the dependent variable based on Pertiwi [5] and Ramadhan [15] is the variable decision process of tourists visiting tourism sites $(\mathrm{Y})$.

\section{RESULTS AND DISCUSSION}

Based on the structural model shown in Figure 1, it is known that the R-square value of the relationship between Patronage buying motives and the decision process of tourists visiting tourist sites is 0.712 . That means $71.2 \%$ of the decision process of tourists visiting tourist sites is explained by patronage buying motives consisting of Tourist Locations, Tourist Location Atmosphere, Facilities at Tourist Sites, Price, and Quality of Service. Meanwhile, $\mathbf{2 8 . 8 \%}$ is explained by other independent variables that are not considered in this study.

The tourist site's coefficient towards the decision process of tourists visiting tourist sites is 0.082 , with t-stat $0.584<1.96$ (Fig. 2). It shows that tourist location doesn't have a significant positive effect on the decision process of tourists visiting tourist sites. So the first research hypothesis $\left(\mathrm{H}_{1}\right)$, which states that the effect of tourist location on the decision process of tourists visiting tourist sites is significant, was rejected. The decision process of tourists visiting tourist sites will indeed increase with the ease of transportation, but the increase is slight. However, this result is not in line with previous research [16]. It's because the location in Milkindo not that far from the Malang city, that still can reach by public transportation even private car.

The tourist location atmosphere path coefficient towards the decision process of tourists visiting tourist sites is 0.196 , t-stat 1.178 $<1.96$ (Fig. 2). It shows that the tourist location atmosphere has a positive but not significant effect on the decision process of tourists visiting tourist sites. So the second hypothesis $\left(\mathrm{H}_{2}\right)$ : the effect of the tourist location atmosphere on the decision process of tourists visiting tourist sites is significant, was rejected. The decision process of tourists visiting tourist sites will indeed increase with each increase in tourist location atmosphere, but the increase is slight. The result is the opposite of Kiswanto [17] because the atmosphere of Milkindo was not demanded to be clean, as one of the indicators stated. The only thing needed in Milkindo that affects visiting decisions is facilities exist in Milkindo. 
Table 1. Operational Definition of Variables

\begin{tabular}{|c|c|c|}
\hline Variables & Indicators & Items \\
\hline \multirow{19}{*}{ 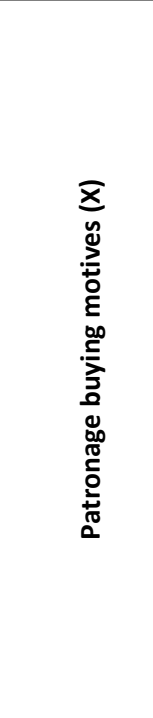 } & \multirow{2}{*}{ Tourist sites $\left(\mathrm{X}_{1}\right)$} & Tourism location strategy $\left(\mathrm{X}_{11}\right)$ \\
\hline & & Ease of transportation in reaching the location $\left(\mathrm{X}_{12}\right)$ \\
\hline & \multirow{4}{*}{ Tourist Location Atmosphere $\left(\mathrm{X}_{2}\right)$} & Pleasure with the atmosphere of the tourist location $\left(\mathrm{X}_{21}\right)$ \\
\hline & & Freedom to carry out tour activities $\left(\mathrm{X}_{22}\right)$ \\
\hline & & Security while on location $\left(\mathrm{X}_{23}\right)$ \\
\hline & & Location cleanliness $\left(\mathrm{X}_{24}\right)$ \\
\hline & \multirow{5}{*}{ Facilities at tourist sites $\left(\mathrm{X}_{3}\right)$} & Compatibility of the design / layout of facilities $\left(X_{31}\right)$ \\
\hline & & Infrastructure design / layout $\left(\mathrm{X}_{32}\right)$ \\
\hline & & Completeness of the feasibility of physical facilities $\left(X_{33}\right)$ \\
\hline & & The feasibility of physical facilities $\left(\mathrm{X}_{34}\right)$ \\
\hline & & The entertainment appeal presented $\left(\mathrm{X}_{35}\right)$ \\
\hline & \multirow{4}{*}{ Price $\left(X_{4}\right)$} & Suit the price of admission with tourist purchasing power $\left(\mathrm{X}_{41}\right)$ \\
\hline & & Suitability of price variations with the needs of tourists $\left(\mathrm{X}_{42}\right)$ \\
\hline & & Suitability of the price of the products at the tourist site $\left(\mathrm{X}_{43}\right)$ \\
\hline & & Quality of Service $\left(X_{45}\right)$ \\
\hline & \multirow{4}{*}{ Service Quality $\left(X_{5}\right)$} & The attraction of the appearance of officers at tourist sites $\left(X_{51}\right)$ \\
\hline & & Reliability of services provided by officers to tourists $\left(X_{52}\right)$ \\
\hline & & Officer responsiveness to tourist complaints $\left(X_{53}\right)$ \\
\hline & & Courtesy and friendliness of officers to tourists $\left(X_{54}\right)$ \\
\hline \multirow{7}{*}{ Decision Prc } & & Need for a vacation $\left(Y_{1}\right)$ \\
\hline & & The desire of tourists in finding additional information $\left(\mathrm{Y}_{2}\right)$ \\
\hline & & Tourist compare with other tourist locations $\left(\mathrm{Y}_{3}\right)$ \\
\hline & ss of Tourists Visiting Tourism (Y) & Attract tourists and choose attractions $\left(\mathrm{Y}_{4}\right)$ \\
\hline & & Frequency of tourists visiting $\left(\mathrm{Y}_{5}\right)$ \\
\hline & & The frequency of tourists planning to visit tourist sites $\left(\mathrm{Y}_{6}\right)$ \\
\hline & & Satisfaction obtained by tourists $\left(\mathrm{Y}_{7}\right)$ \\
\hline
\end{tabular}

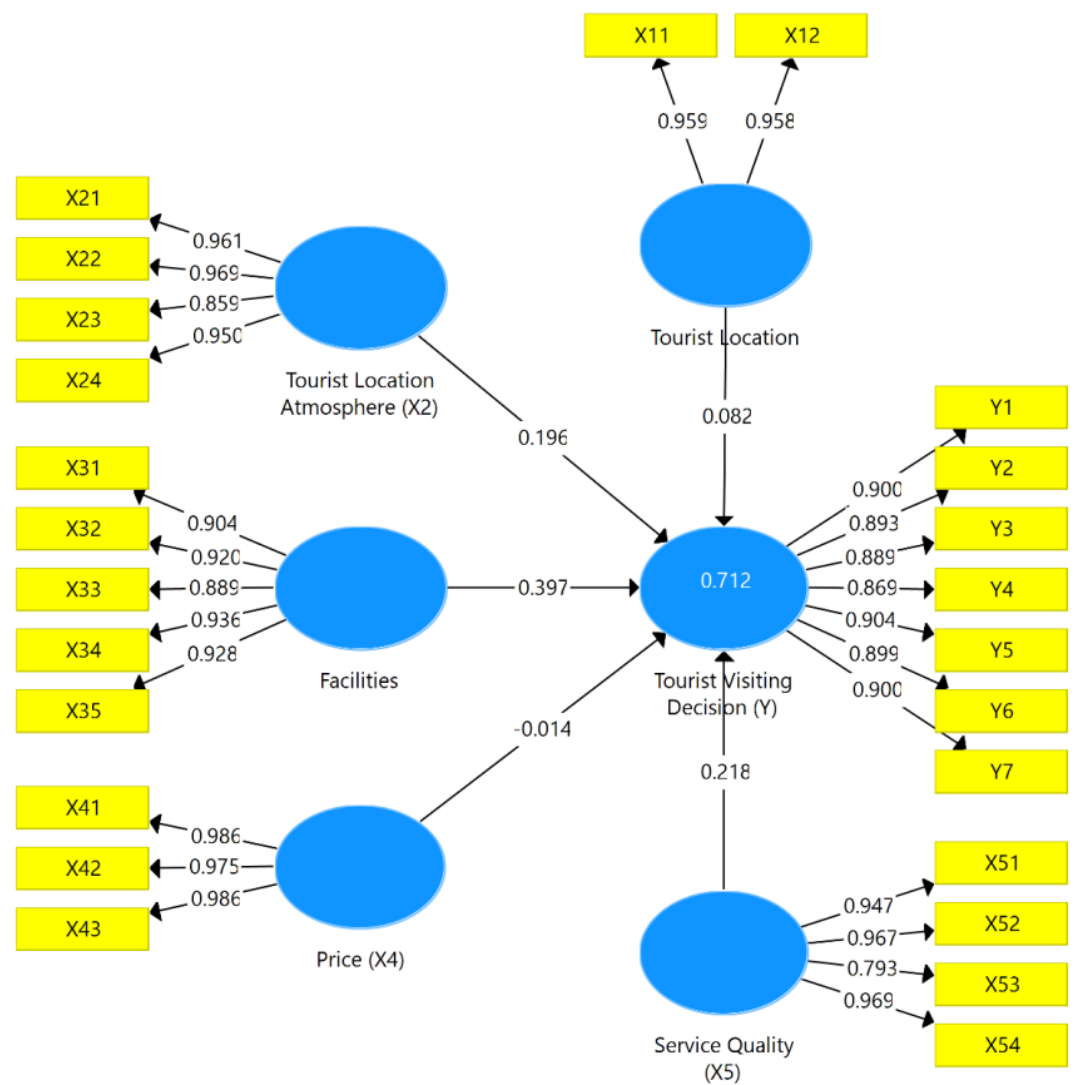

Figure 1. Structural Model 


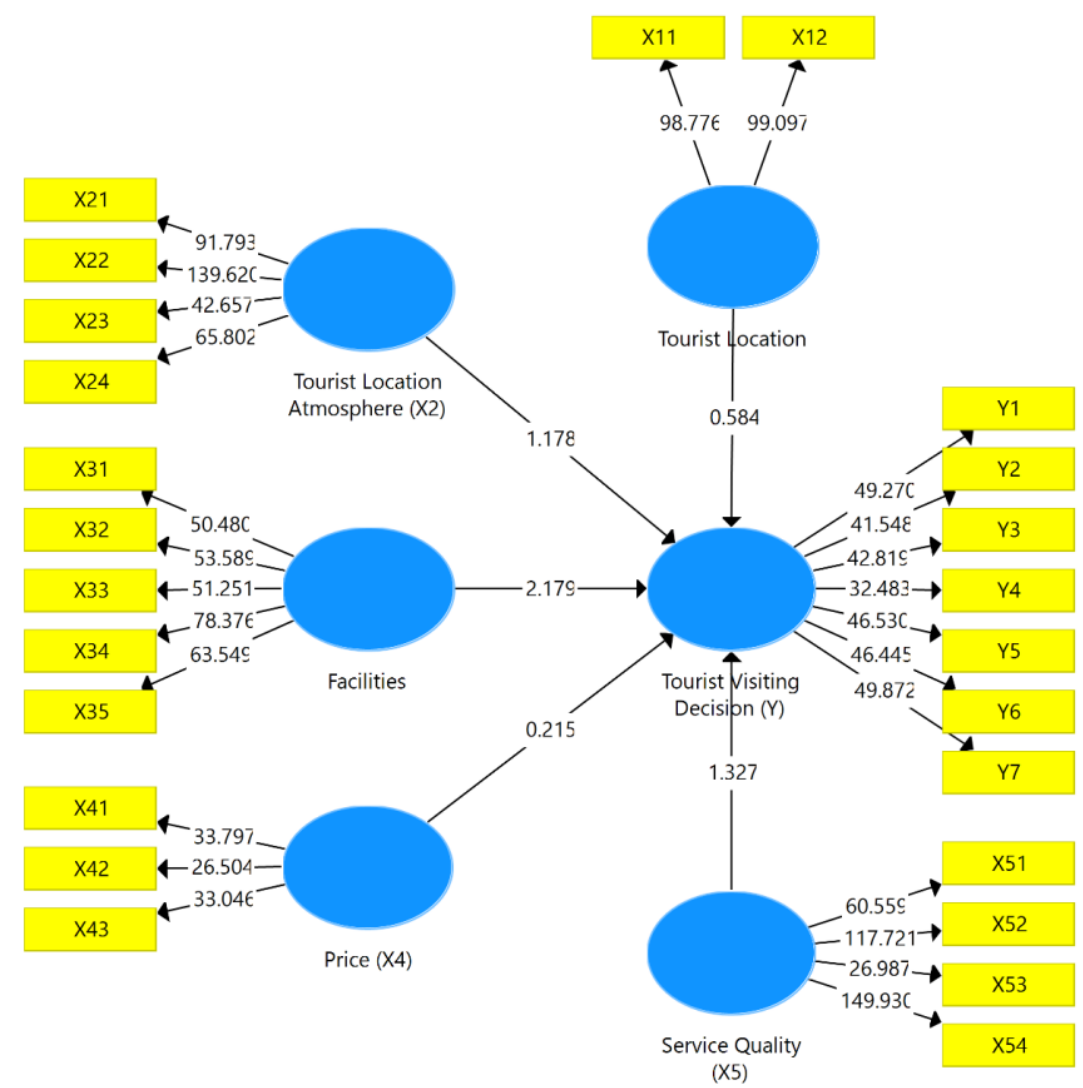

Figure 2. Bootstrapping Output

Facilities at tourist sites path coefficient towards the decision process of tourists visiting tourist sites is 0.397 , t-stat $2.179>1.96$ (Fig. 2). It shows that facilities at tourist sites affect the decision process of tourists visiting tourist sites, in which the direction of the effect is positive and significant. So the third research hypothesis $\left(\mathrm{H}_{3}\right)$, which states that the effect of Facilities at tourist sites on the decision process of tourists visiting tourist sites is significant, is accepted. This research is supported by a previous study that stated facilities have a positive effect significantly toward decision visiting tourism [17]. The decision process of tourists visiting tourist sites will increase dramatically with each increase in facilities at tourist sites.

The price path coefficient towards the decision process of tourists visiting tourist sites is -0.014 , t-stat $0.215<1.96$ (Fig. 2). It shows that price has a negative but not significant effect on the decision process of tourists visiting tourist sites. So the fourth research hypothesis $\left(\mathrm{H}_{4}\right)$, which states that the effect of price on the decision process of tourists visiting tourist sites is significant, is rejected. The decision process of tourists visiting tourist sites will decrease with each increase in price, but the decrease is slight.
This result is in line with previous research that stated price has a negative effect but not significant [16].

The service quality path coefficient towards the decision process of tourists visiting tourist sites is 0.218 , t-stat $1.327<1.96$ (Fig. 2). It shows that service quality affects the decision process of tourists visiting tourist sites. This effect is positive, but it is not significant. This result is not in line with a previous study [16], because in Milkindo, the tourism attraction did not need excellent service to make tourists satisfied. The attraction in Milkindo focuses on how the animal could give a valuable lesson about the process in livestock. So the fifth research hypothesis $\left(\mathrm{H}_{5}\right)$, which states that the effect of price on the decision process of tourists visiting tourist sites is significant, is rejected. The decision process of tourists visiting tourist sites will increase with each increase in service quality, but the increase is slight.

At the indicator level, based on the value of $t-$ statistics, it is known that ease of transportation in reaching the location is stronger enough in reflecting tourist locations than tourism location strategy. The strongest indicator that reflects the tourist location atmosphere is the freedom to 
carry out tour activities, while the weakest is security while on location. The indicator that most strongly reflects facilities at tourist sites is the feasibility of physical facilities, while the weakest is the compatibility of the design/layout of facilities.

Indicators of the suitability of price variations with the needs of tourists are slightly weaker in reflecting prices compared to suit the price of admission with tourist purchasing power and the suitable price for the product at the tourist site. The courtesy and friendliness of officers to tourists indicator is the strongest indicator that reflects service quality, while the weakest is the officer responsiveness to tourist complaints. The strongest indicator that reflects service quality is satisfaction obtained by tourists, while the weakest is attract tourists and choose attractions.

Patronage Buying Motives which have a variable such as location, atmosphere, facilities, price, and service quality of employees/ personnel, have proven that only facilities variable has a significant effect toward tourist decision on visiting Milkindo. These results are supported by recent studies [5,17]. It explained that facilities have a big effect on tourist's decision to visit tourism destinations, in which the direction of the effect is positive.

Based on our observation, the facilities provided by Milkindo are quite diverse. It is ranging from a soccer field as a children's playground, a mini-park, an Instagram able photo booth, a rabbit park, a cowshed, a milk factory, a horse stable that provides horse riding facilities, a trampoline arena, a mini train, an archery arena with a water balloon as a target, clean and spacious toilets, pray room, plenty of chair for rest, and the last is the food court area.

Meanwhile, the location variable is proven to effects the tourists' decisions to visit Milkindo positively, although it is not significant. It was opposite to a previous study [17] that stated the location had a positive and significant influence on tourist visiting decisions. Milkindo has a location near Malang City, so it can be easily reached by the people of Malang City and surrounding areas. The exact location of Milkindo is in Kepanjen, which could be reached within one and a half hours.

The atmosphere variable has a positive effect on tourists' decision to visit Milkindo, although this effect is slight. The results of this study are not in line with a previous study [18] which explained that the atmosphere of the tourist attractions influences the decision of tourists visiting these attractions. According to the results, the strongest indicator of the atmosphere felt at Milkindo is where every tourist freedom to carry out tour activities.

The vast place and location of well-scattered animal cages make tourists feel the freedom to be able to see livestock in Milkindo. However, this does not make Milkindo's atmosphere a significant influence on tourists visiting the place.

Besides, the price variable has been proven as a negative but not significant effect on tourists' decisions to visit Milkindo. The results of this study are supported by previous research [16], which states that prices have a negative and not significant effect on tourist visiting decisions toward tourism destinations. In this case, price is not the main factor determining tourists visiting Milkindo. However, there is an interesting fact that the increasing price of entry tickets will reduce the decision of tourists to visit Milkindo. Interestingly, those states are not significantly affecting the behavior of tourists visiting Milkindo. The price of an entry ticket at Mikindo is affordable at IDR 25,000 with a milking tour package, feeding cows, and getting $250 \mathrm{ml}$ ready to drink cow milk.

Service quality variable affects tourists' decisions to visit Milkindo, but the effect is not great. A different result from previous research [15] stated that service quality significantly influences tourist decisions to visit tourist attractions. The indicator of the service quality variable that has the strongest influence is the level of politeness and friendliness of employees who interact with tourists. This can be seen when the group of tourists first entered Milkindo. Tourists are immediately welcomed by a tour guide and directed into a room with $A C, L C D$, and projector as a facility. Every tourist was invited to see the integrated farming in Milkindo doing, starting from upstream to downstream.

In addition, tourists are invited to find out information about other livestock, besides cows, in Milkindo. After that, tourists are invited to see directly and feel milking from the cows and drink cow's milk after the process. Although the milk that tourists drink is not the result of a tourist's milking, still, it can create an interesting and unforgettable experience for tourists. After completing the cowshed, tourists will be invited to circle other cages, including goats, geese, sheep, and horses. Every service and explanation from the tour guide is delivered in a friendly and polite manner. 


\section{CONCLUSIONS}

The result of this study showed that facilities at tourist sites are the one variable that has a big impact on the decision process of tourists visiting tourist sites, while the tourist location, tourist location atmosphere, and service quality affect the decision process positively but slightly. Meanwhile, the price has a negative but not significant effect. Several things are known to be Milkindo excellence. It includes the convenience of transportation in reaching the location, freedom to conduct tourism activities, the feasibility of physical facilities, the price of admission with tourist purchasing power and the suitability of product prices at tourist sites, the politeness and safety of relations to tourists, and satisfaction obtained by tourists. The findings show that the theory of tourist patronage purchasing motives towards Milkindo can be used as a basis for assessing attractions other than agritourism. In addition, it can be translated with different geographical and demographic conditions because the study is only in the city of Malang, Indonesia.

\section{REFERENCES}

[1] Muslim, C. 2006. Pengembangan sistem Integrasi padi ternak dalam upaya pencapaian swasembada daging di Indonesia : suatu tinjauan evaluasi. Analisis Kebijakan Pertanian 4(3), 227-240.

[2] Directorate General of Animal Husbandry. 2010. Technical guidelines for the Integration of cattle and plant livestock business development. Directorate General of Animal Husbandry, Ministry of Agriculture. Jakarta.

[3] Swarbrooke, J. and S. Horner. 1999. Consumer behavior in tourism. Butterworth - Heinemann. Oxford.

[4] Solomon, R. C. 1999. Corporate roles, personal virtues. an Aristotelean approach to business ethics. In: Donaldson, T. and P. $\mathrm{H}$. Werhane (Eds). Ethical Issues in business. a philosophical approach. Prentice Hall, Upper Saddle River, 81-93.

[5] Pertiwi, F. A. T. 2018. Pengaruh harga, fasilitas wisata, dan atraksi wisata terhadap kepuasan konsumen objek wisata konservasi. Bachelor Thesis. Universitas Sanata Dharma. Yogyakarta.

[6] Loudon, D. L., A. J. D. Bitta. 1993. Consumer behavior, $4^{\text {th }}$ Ed. McGraw-Hill International. USA.
[7] Stanton, M. D. and W. R. Shadish. 1997. Outcome, attrition, and family-couples treatment for drug abuse: a meta-analysis and review of the controlled, comparative studies. Psychological Bulletin 122(2), 17091.

[8] McIntosh, R. W. and C. R. Goeldner. 1986. Tourism principles, practices, philosophies. John Wiley and Sons, Inc. USA.

[9] Kotler, P. and G. Armstrong. 2001. Principles of marketing, $9^{\text {th }} \mathrm{Ed}$. Prentice-Hall. Inc. USA.

[10] Groeppel-Klein, A., E. Thelen, and C. Antretter. 1999. The Impact of shopping motives on store-assessment. In: Dubois, B., T. M. Lowrey, and L. J. Shrum (Eds). E European Advances in Consumer Research 4, 63-72.

[11] Jin, B. and J. O. Kim. 2003. A typology of Korean discount shoppers: shopping motives, store attributes, and outcomes, International Journal of Service Industry Management 14(4), 396-419.

[12] Moschis, G., C. Curasi, and D. Bellenger. 2004. Patronage motives of mature consumers in the selection of food and grocery stores. Journal of Consumer Marketing 21, 123-133.

[13] Yavas, U. and E. Babakus 2009. Modeling patronage behavior: a tri-partite conceptualization. Journal of Consumer Marketing 26(7), 516-26.

[14] Akdon and Riduwan. 2013. Rumus dan data dalam analisis statisitk. Alfabeta. Bandung.

[15] Ramadhan. 2016. Pengaruh kualitas layanan dan promosi terhadap keputusan berkunjung ke tempat wisata Pantai Samudera Baru. Value Journal of Management and Business 1(1), 43-50.

[16] Asdar, D., Lindawati and Irda. 2017. Pengaruh bauran pemasaran jasa dan faktor psikologis terhadap keputusan berkunjung pada Pantai Carocok Painan. Bachelor Thesis. Progam Study of Management, Universitas Bung Hatta. Padang.

[17] Kiswanto, A. H. 2011. Pengaruh harga, lokasi dan fasilitas terhadap keputusan berkunjung wisatawan di Objek Wisata Dampo Awang Beach Rembang. Progam Study of Management, Universitas Negeri Semarang. Semarang.

[18] Pasaribu, F. 2009. Pengaruh patronage buying motives terhadap proses keputusan wisatawan mengunjungı argo wisata dan wana wisata di Sumatera Utara. Jurnal Riset, Akuntansi dan Bisnis 9 (2), 1-26. 